\title{
Mouse 3T3-L1 cells acquire resistance against oxidative stress as the adipocytes differentiate via the transcription factor FoxO
}

\author{
Takayuki Kojima, Takanari Norose, Keita Tsuchiya, Kazuichi Sakamoto*
}

Graduate School of Life and Environmental Sciences, University of Tsukuba

1-1-1 Tennoudai, Tsukuba, Ibaraki 305-8572, Japan

*Corresponding author. Tel.: +81 29853 4676; fax: +81 298534676

E-mail address: sakamoto@biol.tsukuba.ac.jp (K. Sakamoto).

\begin{abstract}
Repression of excessive increase and enlargement of adipocytes that is closely associated with obesity is effective in the prevention and treatment of metabolic syndrome. Generally, apoptosis is induced in cells via a wide variety of intracellular or extracellular substances, and recently, it has been suggested that the FoxO subfamily is involved in the induction of apoptosis. We aimed to elucidate the mechanism of FoxO-mediated apoptosis-induction in the adipocytes under the reactive oxygen species (ROS) stimulus. The treatment of differentiated and undifferentiated 3T3-L1 cells with glucose oxidase (GOD), an enzyme that generates $\mathrm{H}_{2} \mathrm{O}_{2}$, induced apoptosis and led to the accumulation of 8-OHdG. Apoptosis analysis revealed that GOD treatment induced apoptosis in differentiated 3T3-L1 cells less efficiently than in undifferentiated preadipocytes. GOD remarkably increased the levels of Bad, Bax, and Bim - the genes that are actively involved in cell apoptosis. GOD treatment also increased the expression of FoxO3a mRNA and protein. The introduction of FoxO3a-siRNA into 3T3-L1 cells suppressed the oxidative stress-induced expression of Bim mRNA, as well as the GOD-induced apoptosis. Furthermore, the expression of MnSOD, $\mathrm{Cu} / \mathrm{ZnSOD}$, and catalase, as well as of FoxO, increased significantly along with the progression of adipocyte differentiation. These results indicated that ROS-induced apoptosis in undifferentiated 3T3-L1 cells via the expression of FoxO3a, whereas FoxO expression suppressed the ROS-induced apoptosis in differentiated 3T3-L1 cells via the expression of ROS-scavenging enzymes.
\end{abstract}

Keywords $R O S \cdot$ Apoptosis $\cdot 3 T 3-L 1 \cdot F o x O \cdot$ Antioxidative enzymes 


\section{Introduction}

Recently, the increased incidence of lifestyle-related diseases such as diabetes, high blood pressure, and hyperlipemia along with the increased incidence of obesity has become a serious social problem. The fatty tissue that causes obesity comprises 2 types of adipocytes. White adipocytes are distributed throughout the body and are responsible for storing energy in the form of triglycerides [1], while brown adipocytes exist around the neck, armpit, and shoulder blade and play a role in fever induction [2]. Brown adipocytes proliferate only during the fetal period, while white adipocytes can proliferate during the fetal, infancy, and adolescence periods and even after the adolescence stage under nutritious conditions. Hence, an excessive nutrition intake causes an increase in the number of white adipocytes and fatty tissue, resulting in obesity. Recently, it has been shown that white adipocytes are involved in the maintenance of homeostasis by acting as an internal secretary organ that produces adipocytokines such as leptin and adiponectin [3, 4]. In the case of enlarged adipocytes, adipocytokine secretion decreases and the production of tumor necrosis factor (TNF)- $\alpha$, angiotensinogen, and plasminogen activator inhibitor-1 (PAI-1) increases [5-7]. Therefore, to prevent the occurrence and progression of obesity and fat-related diseases, it is essential to repress the fatty tissue and the number of white adipocytes.

Generally, it is widely accepted that apoptosis induction occurs via 2 signaling pathways: the mitochondrial pathway that is mediated by $\mathrm{Bcl} 2$-associated $\mathrm{X}$ protein (Bax), BH3 interacting domain death agonist (Bid), and Bcl2-interacting mediator of cell death (Bim) $[8,9]$, and the death receptor pathway that is mediated by TNF receptor (TNFR), death receptor and TNF receptor superfamily member 6 (Fas) [10-12]. The former is activated under oxidative stress conditions, after exposure to ultraviolet rays, and under physical stress conditions such as heat shock [13-16], and the latter is activated by physiological ligands such as TNF- $\alpha$, TNF-related apoptosis inducing ligand, and Fas ligand $[17,18]$. The activation of any of the two pathways results in the apoptosis of tumor cells and unwanted cells.

Unlike the signaling cascade that is mediated by ligands/receptors, under physical stress conditions, the cell fate is determined on the basis of the level of stress. For example, although low-level oxidative stress induces damage in DNA, lipids, and proteins, activation of p53 causes cell cycle arrest and repair of the damaged substrates by the induction of p21 expression [19]. However, when cell damage is irreparable under excessive stress conditions, p53 induces the expression of apoptosis-inducible genes such as Bax, NADH oxidase (Noxa), and Bcl2 binding component 3 (Puma) and leads to apoptosis via the activation of the mitochondria-mediated signaling pathway [20-22]. Thus, the fate of damaged cells is strictly regulated by p53 under stress conditions.

Recently, many reports have demonstrated that the forkhead-type transcription factor is actively involved in oxidative-stress-induced apoptosis. Forkhead-box class O (FoxO), the mammalian homolog of Daf-16 in nematodes, is divided into 4 subfamilies: FoxO1, FoxO3a, FoxO4, and FoxO6 [23-27]. FoxO is phosphorylated by Akt via the insulin-mediated signaling pathway, translocated from the nuclei to the cytosol by the 14-3-3 protein, and then inactivated [28]. FoxO is activated by various stimuli via the activation of c-Jun N-terminal kinase (JNK) and Silent mating type information regulation 2 homolog (Sirt) and is involved in various physiological functions such as cell cycle regulation, lifespan regulation, and tumor formation [29-31]. In addition, it has been reported that the FoxO subfamily facilitates the expression of antioxidative genes such as Mn-superoxide dismutase (MnSOD) [32-34].

Previously, we analyzed the expression of FoxO in the apoptosis-induced COS-7 and HeLa cells treated with $\mathrm{H}_{2} \mathrm{O}_{2}$. The results of that study indicated that $\mathrm{H}_{2} \mathrm{O}_{2}$ treatment induced the expression of FoxO1, the knockdown of FoxO3a suppressed $\mathrm{H}_{2} \mathrm{O}_{2}$-induced apoptosis, and FoxO induced the expression of apoptosis-inducible genes such as Bim and B-cell leukemia/lymphoma 6 (Bcl-6) [35]. Other investigators have shown that FoxO is one of the critical mediators of reactive oxygen species (ROS)-induced apoptosis [36-38]. These findings revealed that the transcription factor FoxO is actively involved in ROS-induced apoptosis. Although some reports demonstrated that mitochondria-mediated signaling pathway is partially involved 
in the ROS-induced apoptosis in adipocytes [39, 40], there is little information on the role of FoxO in apoptosis induction in adipocytes. We analyzed the physiological effects of ROS on apoptosis induction in preadipocyte/adipocytes and the role of FoxO.

\section{Materials and methods}

Cell line and reagents

3T3-L1 was purchased from Health Science Research Resources Bank (Sennan, Osaka, Japan). Dulbecco's modified Eagle's medium (DMEM High-glucose) was purchased from Sigma-Aldrich (St. Louis, MO, USA). Fetal Bovine Serum (FBS) was purchased from Sanko-junyaku (Chiyoda, Tokyo, Japan).

Cell culture

3T3-L1 preadipocytes were cultured in DMEM containing $10 \% \mathrm{FBS}$ at $37^{\circ} \mathrm{C}$. Cells were plated at a density of $2.7 \times 10^{5}$ cells in 60 $\mathrm{mm}$ culture dish, $2.0 \times 10^{4}$ cells/well in 48 well plates, $5.0 \times 10^{3}$ cells/well in 96 well plates and used for each assays. Differentiation of preadipocytes into adipocytes was induced as previously described [41]; briefly, cells were cultured to overconfluent and treated with DMEM containing $0.25 \mu \mathrm{M}$ dexamethasone (Sigma-Aldrich), $0.5 \mathrm{mM}$ 3-iso-butyl-1-methylxanthine (IBMX, Sigma-Aldrich) and $10 \mu \mathrm{g} / \mathrm{ml}$ insulin (Wako, Chuo, Osaka, Japan) for 2 days. Cells were cultured with DMEM containing 5 $\mu \mathrm{g} / \mathrm{ml}$ insulin for more 2 days and then cultured with DMEM for 4 days.

Detection of 8-OHdG

Cells were cultured in 48 well plates and treated with DMEM containing $60 \mathrm{mU} / \mathrm{ml}$ Glucose Oxidase (GOD, Sigma-Aldrich) for $6 \mathrm{~h}$. After GOD treatment [42], cells were fixed with 4\% paraformaldehyde (PFA, Wako) in phosphate-buffered saline (PBS;pH 7.4) for overnight. The intracellular accumulation of 8-OHdG was detected with DAKO LSAB Kit2 (Dako Japan, Bunkyo, Tokyo, Japan).

MTT assay

Cells were cultured in 96 well plates and treated with DMEM containing $60 \mathrm{mU} / \mathrm{ml} \mathrm{GOD.} \mathrm{MTT} \mathrm{assay} \mathrm{was} \mathrm{performed} \mathrm{by} \mathrm{treating}$ the cells with DMEM containing $5 \mathrm{mg} / \mathrm{ml}$ Thiazolyl Blue Tetrazolium Bromide (MTT, Sigma-Aldrich) for $3 \mathrm{~h}$. MTT formazan were extracted with $0.04 \mathrm{~N} \mathrm{HCl}$ in isopropanol and then absorbance at $570 \mathrm{~nm}$ was measured with a microplate reader (Ultramark, BIO-RAD, Arakawa, Tokyo, Japan) to assess the cell viability.

Staining of apoptotic cells

Cells were cultured in 96 well plates and treated with DMEM containing $60 \mathrm{mU} / \mathrm{ml} \mathrm{GOD}$ with or without $100 \mathrm{U} / \mathrm{ml}$ Catalase (CAT, Wako). The staining of apoptotic cells was performed using APOPercentage Apoptosis Assay Kit (Biocolor, Carrickfergus, Antrim, UK). The cells were treated by dye mixture (DMEM containing 5\% APOPercentage dye and GOD with or without CAT) for $30 \mathrm{~min}$. Then cells were observed under microscope and the intracellular dye was extracted with dye release reagent. The 
absorbance at 550-645nm was measured with Ultramark to assess the level of apoptotic cells.

Hoechst staining

Cells were cultured in $60 \mathrm{~mm}$ dish and treated with DMEM containing $60 \mathrm{mU} / \mathrm{ml} \mathrm{GOD}$ for $6 \mathrm{~h}$. Then cells were fixed with $4 \%$ PFA in PBS for overnight. Cells were treated with 1mM Hoechst 33258 (Sigma-Aldrich) and then observed under fluorescent microscope $(350 \mathrm{~nm})$.

Western Blotting

Cells were cultured in $60 \mathrm{~mm}$ dish and treated by DMEM containing $60 \mathrm{mU} / \mathrm{ml}$ GOD for $3 \mathrm{~h}$. Cells were lysed in a buffer (50mM Tris-HCl, 2\% SDS, 6\% 2-mercaptoethanol, 10\% glycerol, $1 \mathrm{mM} \mathrm{PMSF,} 2 \mu \mathrm{g} / \mathrm{ml}$ Leupeptin) and homogenized with a supersonicator (UP-50H, B. Braun Biotech International GmbH, Melsungen, Germany) for 2 min. The cell lysates were separated with SDS-PAGE and blotted on a PVDF membrane (OPTIRAN BA-S85 NC, Schleicher\& Schuell BioScience, Keene, NH, USA). The membrane was blocked with $5 \%$ skim milk for 60 min and incubated with a primary antibody in TBS-T (10mM Tris- $\mathrm{HCl}$, $0.15 \mathrm{M} \mathrm{NaCl}, 0.1 \%$ Tween 20 ) for overnight at $4^{\circ} \mathrm{C}$. Then membrane was incubated with secondary antibody for $1 \mathrm{~h}$ at $\mathrm{RT}$. The membranes were treated with the LumiGLO reagent (Cell Signaling Technology, Danvers, MA, USA) and the protein bands were analyzed using chemiluminescence (Las1000, FUJI FILM, Minato, Tokyo, Japan) and Image Gauge Software (FUJI FILM).

Preparation of nuclear and cytosolic fractions

Cells were cultured in $60 \mathrm{~mm}$ dish and treated with DMEM containing $60 \mathrm{mU} / \mathrm{ml}$ GOD for $3 \mathrm{~h}$. The nuclear and cytosolic fractions were prepared using the methodology reported by Masuda et al. [43]. Briefly, cells were lysed in buffer A (10mM HEPES, $15 \mathrm{mM} \mathrm{KCl}, 2 \mathrm{mM} \mathrm{MgCl} 2,0.1 \mathrm{mM}$ EDTA, $1 \mathrm{mM}$ DTT, $0.5 \mathrm{mM}$ PMSF, $10 \mu \mathrm{g} / \mathrm{ml}$ Leupeptin) and centrifuged. The cell pellet was resuspended in buffer B $(0.2 \%$ NP- $40,10 \mathrm{mM}$ HEPES, $15 \mathrm{mM} \mathrm{KCl}, 2 \mathrm{mM} \mathrm{MgCl} 2,0.1 \mathrm{mM}$ EDTA, $1 \mathrm{mM}$ DTT, $0.5 \mathrm{mM}$ PMSF, $10 \mu \mathrm{g} / \mathrm{ml}$ Leupeptin) and centrifuged. The supernatant was used as cytosolic fraction. The pellet was resuspended in buffer $\mathrm{S}\left(0.25 \mathrm{M}\right.$ Sucrose, $10 \mathrm{mM}$ HEPES, $15 \mathrm{mM} \mathrm{KCl}, 2 \mathrm{mM} \mathrm{MgCl}_{2}, 0.1 \mathrm{mM}$ EDTA, $1 \mathrm{mM}$ DTT, $0.5 \mathrm{mM}$ PMSF, $10 \mu \mathrm{g} / \mathrm{ml}$ Leupeptin) and centrifuged. The pellet was resuspended in buffer D (50mM HEPES, $400 \mathrm{mM} \mathrm{KCl}, 0.1 \mathrm{mM}$ EDTA, $10 \%$ Glycerol, $1 \mathrm{mM}$ DTT, $0.5 \mathrm{mM}$ PMSF, $10 \mu \mathrm{g} / \mathrm{ml}$ Leupeptin) and mixed well. The sample was incubated on ice for $30 \mathrm{~min}$ and then centrifuged. The supernatant was used as nuclear fraction.

FoxO knockdown by siRNA

Adenovirus for RNAi of FoxO were constructed; Ad-FoxO1Si (FoxO1-siRNA), Ad-FoxO3aSi (FoxO3a-siRNA), Ad-NCSi (siRNA for non specific siRNA) [44]. Adenovirus was amplified according to the procedure described by TaKaRa. The cells plated in $60 \mathrm{~mm}$ dish at $6.0 \times 10^{5}$ cells were infected by adenovirus (1000 plaque-forming units (PFU)/cell) and incubated for 4 days.

Reverse transcription-PCR and real-time PCR analysis

Cells were cultured on each plates, and the total RNA was extracted by a standard acid-GTC-phenol extraction method reported by Chomczynski et al [45]. After DNase treatment of RNA, the cDNA was synthesized by M-MLV Reverse 
Transcriptase (Takara Bio, Otsu, Shiga, Japan), and subjected for PCR using the primers indicated in Table 1. Real-time PCR was performed using SYBR Premix Ex Taq (Takara) and Thermal Cycler Dice RealTime System TP800 (Takara) with the condition (40 cycles at $95{ }^{\circ} \mathrm{C}$ for $5 \mathrm{sec}$ and at $60{ }^{\circ} \mathrm{C}$ for $30 \mathrm{sec}$ ) using the following primers; $\beta$-actin (forward, 5'-CTGTGCTGCTCACCGAGG-3'; reverse, 5'-TGCCACAGGATTCCATAC-3'), Bim (forward, 5'-CAACACAAACCCCAAGTCC-3'; reverse, 5'-CTGTGCAATCCGTATCTCC-3'). PCR was performed in triplicate using 4 independent samples.

Image analysis and statistical analysis

Image analysis was performed using ImageJ, a public domain Java-based image-processing program inspired by NIH Image [46]. Results are expressed as mean \pm standard deviation. Comparisons between groups were made with the Student's $t$-test.

Differences were considered significant when $P<0.05$.

\section{Results}

Oxidative stress-induced cell death in 3T3-L1 cells was suppressed by differentiation

The efficiency of ROS to induce cell death was assessed using both undifferentiated and differentiated 3T3-L1 cells. These cells were subjected to oxidative stress and then observed under a microscope; subsequently, cell viability was analyzed. Glucose oxidase (GOD) was used as a source of oxidative stress for stably supplying $\mathrm{H}_{2} \mathrm{O}_{2}$. Accumulation of 8-OHdG-the marker of DNA damage induced by ROS—was increased after treating the cells with $60 \mathrm{mU} / \mathrm{ml}$ GOD for $6 \mathrm{~h}$. 8-OHdG abundantly accumulated in the differentiated cells with or without GOD treatment (Fig. 1a). The 3-(4,5-dimethylthiazol-2-yl)-2,5-diphenyltetrazoliumbromide (MTT) assay revealed that the cell viability at $9 \mathrm{~h}$ incubation decreased to $6 \%$ of that at 0 -h incubation in preadipocytes, whereas it reduced to $33 \%$ of that at 0 -h incubation in differentiated cells (Fig. 1b). These results suggested that differentiated 3T3-L1 cells acquired resistance to oxidative stress.

Oxidative stress-induced apoptosis in 3T3-L1 cells was suppressed by differentiation

To determine whether ROS stress induced apoptosis, we analyzed the GOD-treated cells by APOPercentage apoptosis assay. The absorbance, which represents the quantity of dye taken up by apoptotic cells, increased more significantly in preadipocytes than in differentiated adipocytes. GOD-induced apoptosis in the 3T3-L1 cells was completely suppressed by the addition of $100 \mathrm{U} / \mathrm{ml}$ catalase (Fig. 2a). $\mathrm{H}_{2} \mathrm{O}_{2}$ treatment obviously induced the intake of the dye, suggesting that ROS induced apoptosis in the 3T3-L1 cells (Fig. 2b). Hoechst 33258 staining revealed that GOD-induced apoptosis decreased as differentiation progressed in 3T3-L1 cells (Fig. 2c). These results demonstrated that apoptosis was induced in 3T3-L1 by GOD treatment and that differentiated 3T3-L1 cells acquired resistance to oxidative stress.

Expression of FoxO3a mRNA and protein increased by oxidative stress

Previously, we reported that the expression of FoxO1, one of the subtypes of the FoxO subfamily, increased in other types of cells that were subjected to oxidative stimulus [35]. In this study, we confirmed whether ROS enhanced the expression of FoxO in undifferentiated and differentiated adipocytes. In the undifferentiated and differentiated adipocytes treated with GOD for $3 \mathrm{~h}$, the 
expression of FoxO3a mRNA increased significantly, while that of FoxO4 mRNA increased slightly (Fig. 3a). Increased expression of FoxO3a protein similar to the levels of its mRNA expression was observed in both cells treated with GOD (Fig. 3b). And slightly increased expression of FoxO1 and FoxO4 proteins were observed in differentiated adipocytes only (Fig. 3b).

Nuclear and cytoplasmic levels of FoxO3a protein increased by oxidative stress

To examine the intracellular localization of FoxO under oxidative stress conditions, we analyzed the expression of FoxO1 and FoxO3a protein in the nuclear and cytosolic fractions of the 3T3-L1 cells. In undifferentiated GOD-treated 3T3-L1 cells, the level of FoxO3a protein increased in both the nuclear and cytosolic fractions (Fig. 4a). Similar expression pattern for FoxO3a was observed in GOD-treated differentiated 3T3-L1 cells. Moreover, the level of FoxO1 protein increased in the nuclei only (Fig. 4b). These results indicated that FoxO3a was included in the apoptosis signaling pathway induced by oxidative stress in preadipocytes and adipocytes.

GOD stimulation induced apoptosis by increasing Bim expression via FoxO3a activation

Previously, we [35] and other researchers [36, 37] have demonstrated that the FoxO subfamily induces apoptosis by inducing the expression of apoptotic genes such as Bim. We identified the genes that showed increased expression under oxidative stimulus in 3T3-L1 cells. 3T3-L1 preadipocytes were treated with $60 \mathrm{mU} / \mathrm{ml}$ of GOD for $3 \mathrm{~h}$, and the expression of genes involved in apoptosis was analyzed. The mRNA expression of Bad, Bax, and Bim was increased in GOD-treated cells (Fig. 5a). To demonstrate whether the genes encoding these mRNAs were the actual targets of FoxO3a, we investigated the mRNA expression of Bad, Bax, and Bim in FoxO3a-RNAi-transfected cells. GOD-induced mRNA expression of Bim was suppressed by FoxO3a RNAi, while that of Bad and Bax was unaffected (Fig. 5b, c). Furthermore, GOD-induced apoptosis was suppressed by the knockdown of FoxO3a (Fig. 5d). These results demonstrated that ROS induced the expression of Bim via the activation of FoxO3a, thereby inducing apoptosis in 3T3-L1 cells.

Resistance against oxidative stress was acquired by differentiated 3T3-L1 cells via the activation of FoxO

We considered that the suppression of GOD-induced apoptosis in differentiated 3T3-L1 cells was caused by the FoxO-mediated increase in the expression of antioxidative genes. Therefore, we compared the expression of antioxidative genes (such as MnSOD, $\mathrm{Cu} / \mathrm{ZnSOD}$, catalase, and glutathione peroxidase (GPX1)) and the expression of the members of the FoxO subfamily (such as FoxO1, FoxO3a, and FoxO4) in undifferentiated and differentiated 3T3-L1 cells. The results of RT-PCR revealed that the expression of antioxidative genes and FoxO subfamily members significantly increased with the differentiation of adipocytes (Fig. 6a). Western blot analysis revealed a similar tendency of MnSOD protein expression (Fig. 6b). The results of RT-PCR revealed that the expression of MnSOD and GPX1 mRNA as well as of the FoxO1 increased in GOD-treated cells $(0.2 \mathrm{mU} / \mathrm{ml}$ of GOD for 4 days) (Fig. 6c). The increase in the expression of these mRNAs was completely suppressed by FoxO1 RNAi, while FoxO3a knockdown had no effect on the expression of these mRNAs (data not shown). These results suggest that differentiated 3T3-L1 cells acquire resistance against oxidative stress by increasing the expression of antioxidative genes (such as MnSOD, Cu/ZnSOD, catalase, and GPX1). In addition, GOD induced the FoxO1-mediated expression of MnSOD and GPX1.

\section{Discussion}


Obesity is caused by corpulence and the overproduction of white adipocytes, which are involved in energy preservation and internal secretion, and is deeply associated with the development of metabolic syndrome accompanied by diabetes, high blood pressure, and hyperlipemia due to the derangement of adipocytokines secretion. Suppression of corpulence and overproduction of white adipocytes is supposed to be effective in the prevention and treatment of metabolic syndrome. Therefore, we investigated the induction of apoptosis in adipocytes under oxidative stress conditions.

Apoptosis is a form of natural cell death that is required for the removal of unwanted cells. Recently, we [35] and other researchers [36-38] have demonstrated that FoxO subfamily is associated with the induction of apoptosis. In this study, we aim to elucidate the role of FoxO subfamily in the induction of apoptosis in preadipocytes and adipocytes under oxidative stress conditions. Thus far, many studies have demonstrated that the FoxO subfamily is involved in the expression of apoptotic genes $[38,47,48]$. Because oxidative stimulus-induced apoptosis was suppressed by the knockdown of FoxO3a and the level of FoxO1 protein increased along with apoptosis progression [35], we assumed that these two proteins could be actively involved in ROS-induced apoptosis signaling pathway. In this study, we demonstrated that the level of FoxO3a protein increased with apoptosis progression in 3T3-L1 cells that were treated with GOD (Fig. 3), suggesting that the oxidative stimulus induced apoptosis via the activation of FoxO3a. Although a previous study reported that ROS facilitated the nuclear localization of FoxO3a [48], we demonstrated that the level of FoxO3a protein increased in both the nuclei and cytosol of the 3T3-L1 cells (Fig. 4). We assume that the translocation of FoxO3a from the nuclei to cytosol had already begun in the cells at $3 \mathrm{~h}$ after GOD treatment.

Majority of the apoptotic signals integrated in the mitochondria facilitate apoptosis via the translocation of apoptotic proteins into the cytosol. The release of apoptotic proteins is regulated by a protein family, namely, Bcl-2 family. A member of the Bcl-2 family Bim, one of the BH3-only proteins, is usually located in the cytosol and is transferred to the mitochondria when apoptosis is induced [49]. The expression of Bim is induced by the activation of FoxO3a in response to an apoptotic stimulus [48]. Our study revealed that the expression of Bad, Bax, and Bim mRNA was increased by FoxO3a when GOD induced apoptosis in 3T3-L1 cells (Fig. 5a). Moreover, knockdown of FoxO3a mRNA by FoxO3a-siRNA suppressed the expression of Bim (Fig. 5b, c) and GOD-induced apoptosis (Fig. 5d). These results demonstrated that the increase in Bim expression via FoxO3a activation is significantly involved in the GOD-induced apoptosis in 3T3-L1 cells.

Interestingly, the expressions of MnSOD, $\mathrm{Cu} / \mathrm{ZnSOD}$, catalase, and GPX1 mRNA increased remarkably along with the differentiation of 3T3-L1 cells (Fig. 6a), indicating that differentiated 3T3-L1 cells acquired resistance against oxidative stimulus (Fig. 1, 3). It is generally considered that the expression of the abovementioned enzymes is regulated by FoxO subfamily [32-34]. There was a remarkable increase in the expression of FoxO1 mRNA and a slight increase in the levels of FoxO3a and FoxO4 mRNA as the 3T3-L1 cells differentiated (Fig. 6a). Although the knockdown of FoxO1 expression suppressed the GOD-induced expression of MnSOD and GPX1 mRNA (Fig. 6c), transfection of cells with FoxO3a siRNA did not affect their expression (data not shown). These results suggested that FoxO1-mediated induction of MnSOD, Cu/ZnSOD, catalase, and GPX1 expression is critically involved in acquiring resistance against oxidative stress that was observed in differentiated 3T3-L1 cells. It looks that differentiated cells were dyed more thickly than undifferentiated cells (Fig. 1a). Although we have no evidence to explain why 8-OHdG was accumulated abundantly in differentiated cells, it is possible that ROS that was generated endogenously during the differentiation accumulated and affected continuously to the DNA. As the result of endogenous ROS stress, the expression of FoxO and antioxidant enzymes was increased more abundantly in differentiated cells than in undifferentiated cells. Otherwise, ROS sensitive cells were possibly killed by the endogenous ROS during differentation.

In this study, we demonstrated that ROS-induced apoptosis was suppressed in 3T3-L1 cells by the activation of antioxidative enzymes whose expression was partially regulated by FoxO1 through cell differentiation. In addition, we demonstrated that oxidative stimulus induced apoptosis in 3T3-L1 cells via the FoxO3a-meadited increase in the expression of Bim. These results indicate that FoxO subfamily critically regulates apoptosis via 2 approaches: induction and suppression of apoptosis. Further 
studies are required to elucidate how FoxO switches these roles in 3T3-L1 cells during differentiation. Because previous study reported that induction of adipocyte apoptosis sometimes causes insulin intolerance, adipocyte apoptosis doesn't always give beneficial amelioration of metabolic syndrom [50]. However, we believe that by elucidating the molecular mechanisms of apoptosis in adipocytes, a promising therapeutic method for controlling obesity and diabetes can be established in the future.

Acknowledgements This work was supported in part by Grants-in-Aid for Scientific Research from the Ministry of Education, Science, Sports, and Culture of Japan. We wish to thank Dr. Keisuke Munekata (University of Tsukuba) for providing adenovirus (Ad-FoxO1Si, Ad-FoxO3aSi, Ad-NCSi) for RNAi and to his helpful discussion.

\section{References}

1. Patrick S, Kajimura S, Spiegelman BM (2009) Transcriptional control of brown adipocyte development and physiological function-of mice and men. Genes Dev 23:788-797

2. Cannon B, Nedergaard J (2004) Brown Adipose Tissue: Function and Physiological Significance. Physiol Rev 84:277-359

3. Trayhurn P, Beattie JH (2001) Physiological role of adipose tissue: white adipose tissue as endocrine and secretory organ. Proc Nutr Soc 60:329-339

4. Ouchi N, Kihara S, Arita Y et al (1999) Novel Modulator for Endothelial Adhesion Molecules: Adipocyte-Derived Plasma Protein Adiponectin. Circulation 100:2473-2476

5. Coppack SW (2001) Pro-inflammatory cytokines and adipose tissue. Proc Nutr Soc 60:349-356

6. Safonova I, Aubert J, Negrel R, Ailhaud G (1997) Regulation by fatty acids of angiotensinogen gene expression in preadipose cells. Biochem. J 322:235-239

7. Eriksson P, Reynisdottir S, Lönnqvist F et al (1998) Adipose tissue secretion of plasminogen activator inhibitor-1 in non-obese and obese individuals. Diabetologia 41:65-71

8. Kuwana T, Mackey MR, Perkins G et al (2002) Bid, Bax, and Lipids Cooperate to Form Supramolecular Openings in the Outer Mitochondrial Membrane. Cell 111:331-342

9. Malhi H, Bronk SF, Werneburg NW, Gores GJ (2006) Free Fatty Acids Induce JNK-dependent Hepatocyte Lipoapoptosis. J Biol Chem 281:12093-12101

10. Medvedev AE, Espevik T, Ranges G, Sundan A (1996) Distinct Roles of Two Tumor Necrosis Factor (TNF) Receptors in Modulating TNF and Lymphotoxin $\alpha$ Effects. J Biol Chem 271:9778-9784

11. Cheng J, Hylander BL, Baer MR et al (2006) Multiple mechanisms underlie resistance of leukemia cells to Apo2 Ligand/TRAIL. Mol Cancer Ther 5:1844-1853

12. Yonehara S (2002) Death receptor Fas and autoimmune disease: from the original generation to therapeutic application of agonistic anti-Fas monoclonal antibody. Cytokine Growth Factor Rev 13:393-402

13. Robertson JD, Datta K, Kehrer JP (1997) Bcl- $\mathrm{x}_{\mathrm{L}}$ Overexpression Restricts Hear-Induced Apoptosis and Influences hsp70, bcl-2, and Bax Protein Levels in FL5.12 Cells. Biochem Biophys Res Commun 241:164-168

14. Pradhan S, Kim HK, Thrash CJ et al (2008) A critical role for the proapoptotic protein bid in ultraviolet-induced immune suppression and cutaneous apoptosis. J Immunol 181:3077-3088

15. Jin HO, Park IC, An S et al (2006) Up-regulation of Bak and Bim via JNK downstream pathway in the response to nitric oxide in human glioblastoma cells. J Cell Physiol 206:477-486

16. Pimentel DR, Amin JK, Xiao L et al (2001) Reactive oxygen species mediate amplitude-dependent hypertrophic and apoptotic 
responses to mechanical stretch in cardiac myocytes. Circ Res 89:453-460

17. Kitson J, Raven T, Jiang YP et al (1996) A death-domain-containing receptor that mediates apoptosis. Nature 384:372-375

18. Schneider P, Bodmer JL, Thome M et al (1997) Characterization of two receptors for TRAIL. FEBS Lett 416:329-334

19. Helt CE, Rancourt RC, Staversky RJ, O'Reilly MA (2001) p53-dependent induction of p21(Cip1/WAF1/Sdi1) protects against oxygen-induced toxicity. Toxicol Sci 63:214-222

20. Chipuk JE, Kuwana T, Bouchier-Hayes L et al (2004) Direct activation of Bax by p53 mediates mitochondrial membrane permeabilization and apoptosis. Science 303:1010-1014

21. Oda E, Ohki R, Murasawa H et al (2000) Noxa, a BH3-Only Member of the Bcl-2 Family and Candidate Mediator of p53-Induced Apoptosis. Science 288:1053-1058

22. Jeffers JR, Parganas E, Lee Y et al (2003) Puma is an essential mediator of p53-dependent and -independent apoptotic pathways. Cancer Cell 4:321-328

23. Galili N, Davis RJ, Fredericks WJ et al (1993) Fusion of a fork head domain gene to PAX3 in the solid tumour alveolar rhabdomyosarcoma. Nat Genet 5:230-235

24. Anderson MJ, Viars CS, Czekay S et al (1998) Cloning and characterization of three human forkhead genes that comprise an FKHR-like gene subfamily. Genomics 47:187-199

25. Hillion J, Coniat ML, Jonveaux P et al (1997) AF6q21, a Novel Partner of the MLL Gene in t(6; 11)(q21; q23), Defines a Forkhead Transcriptional Factor Subfamily. Blood 90:3714-3719

26. Borkhardt A, Repp R, Haas OA et al (1997) Cloning and characterization of AFX, the gene that fuses to MLL in acute leukemias with a $\mathrm{t}(\mathrm{X} ; 11)(\mathrm{q} 13 ; \mathrm{q} 23)$. Oncogene 14:195-202

27. Jacobs FM, van der Heide LP, Wijchers PJ et al (2003) FoxO6, a novel member of the FoxO class of transcription factors with distinct shuttling dynamics. J Biol Chem 278:35959-35967

28. Vogt PK, Jiang H, Aoki M (2005) Triple layer control: phosphorylation, acetylation and ubiquitination of FoxO proteins. Cell Cycle 4:908-913

29. Seoane J, Le HV, Shen L et al (2004) Integration of Smad and forkhead pathways in the control of neuroepithelial and glioblastoma cell proliferation. Cell 117:211-223

30. van der Horst A, Tertoolen LG, de Vries-Smits LM et al (2004) FoxO4 is acetylated upon peroxide stress and deacetylated by the longevity protein hSir2(SIRT1). J Biol Chem 279:28873-28879

31. Modur V, Nagarajan R, Evers BM, Milbrandt J (2002) FoxO proteins regulate tumor necrosis factor-related apoptosis inducing ligand expression. Implications for PTEN mutation in prostate cancer. J Biol Chem 277:47928-47937

32. Essers MA, Weijzen S, de Vries-Smits AM et al (2004) FoxO transcription factor activation by oxidative stress mediated by the small GTPase Ral and JNK. EMBO J 23:4802-4812

33. Kops GJ, Dansen TB, Polderman PE et al (2002) Forkhead transcription factor FoxO3a protects quiescent cells from oxidative stress. Nature 419:316-321

34. Alcendor RR, Gao S, Zhai P et al (2007) Sirt1 Regulates Aging and Resistance to Oxidative Stress in the Heart. Circ Res $100: 1512-1521$

35. Nakamura T, Sakamoto K (2008) Forkhead transcription factor FoxO subfamily is essential for reactive oxygen species-induced apoptosis. Mol Cell Endocrinol 281:47-55

36. Alikhani M, Maclellan CM, Raptis M et al (2007) Advanced glycation end products induce apoptosis in fibroblasts through activation of ROS, MAP kinases, and the FoxO1 transcription factor. Am J Physiol Cell Physiol 292:C850-C856

37. van Gorp AG, Pomeranz KM, Birkenkamp KU et al (2006) Chronic protein kinase B (PKB/c-akt) activation leads to apoptosis induced by oxidative stress-mediated Foxo3a transcriptional up-regulation. Cancer Res 66:10760-10769

38. Urbich C, Knau A, Fichtlscherer S et al (2005) FoxO-dependent expression of the proapoptotic protein Bim: pivotal role for 
apoptosis signaling in endothelial progenitor cells. FASEB J 19:974-976

39. Yang JY, Della-Fera MA, Rayalam S, Baile CA (2007) Effect of xanthohumol and isoxanthohumol on 3T3-L1 cell apoptosis and adipogenesis. Apoptosis 12:1953-1963

40. Yang JY, Della-Fera MA, Hausman DB, Baile CA (2007) Enhancement of ajoene-induced apoptosis by conjugated linoleic acid in 3T3-L1 adipocytes. Apoptosis 12:1117-1128

41. Student AK, Hsu RY, Lane MD (1980) Induction of Fatty Acid Synthetase Synthesis in Differentiating 3T3-L1 Preadipocytes. J Biol Chem 255:4745-4750

42. Kozlovsky N, Rudich A, Potashnik R, Bashan N (1997) Reactive oxygen species activate glucose transport in L6 myotubes. Free Radic Biol Med 23:859-869

43. Masuda ES, Tokumitsu H, Tsuboi A et al (1993) The granulocyte-macrophage colony-stimulating factor promoter cis-acting element CLE0 mediates induction signals in T cells and is recognized by factors related to AP1 and NFAT. Mol Cell Biol 13:7399-7407

44. Munekata K, Sakamoto K (2009) Forkhead transcription factor Foxo1 is essential for adipocyte differentiation. In Vitro Cell Dev Biol Anim in press

45. Chomczynski P, Sacchi N (1987) Single-step method of RNA isolation by acid guanidinium thiocyanate-phenol-chloroform extraction. Anal Biochem 162:156-159

46. Abramoff MD, Magelhaes PJ, Ram SJ (2004) Image Processing with ImageJ. Biophoton Int 11:36-42

47. Alikhani M, Alikhani Z, Graves DT (2005) FoxO1 functions as a master switch that regulates gene expression necessary for tumor necrosis factor-induced fibroblast apoptosis. J Biol Chem 280:12096-12102

48. Barreyro FJ, Kobayashi S, Bronk SF et al (2007) Transcriptional Regulation of Bim by FoxO3A Mediates Hepatocyte Lipoapoptosis. J Biol Chem 282:27141-27154

49. Tong T, Ji J, Jin S et al (2005) Gadd45a Expression Induces Bim Dissociation from the Cytoskeleton and Translocation to Mitochondria. Mol Cell Biol 25:4488-4500

50. Pajvani UB, Trujillo ME, Combs TP et al (2005) Fat apoptosis through targeted activation of caspase 8: a new mouse model of inducible and reversible lipoatrophy. Nat Med 11:797-803

\section{Legends to Figures}

Fig. 1 GOD caused cell death of undifferentiated and differentiated 3T3-L1. a 3T3-L1 cells were cultured to 80\% confluent and differentiation was induced by DMI method. Cells were treated by $60 \mathrm{mU} / \mathrm{ml}$ GOD for $6 \mathrm{~h}$. After fixation by 4\% PFA, 8-OHdG was detected with anti-8-OHdG antibody. b Undifferentiated and differentiated 3T3-L1 cultured in 96 well plate were treated by $60 \mathrm{mU} / \mathrm{ml} \mathrm{GOD}$ for each period, and then replaced with medium containing $5 \mathrm{mg} / \mathrm{ml}$ MTT. The level of MTT formazan was measured to analyze the cell viability. Data represent mean \pm SD of three separate experiments. Undif undifferentiated cell; Dif differentiated cell.

Fig. 2 GOD induced apoptosis of undifferentiated and differentiated 3T3-L1. a Undifferentiated and differentiated 3T3-L1 cultured in 96 well plate were treated by $60 \mathrm{mU} / \mathrm{ml}$ GOD with or without $100 \mathrm{U} / \mathrm{ml}$ catalase for each period. The efficiency of apoptosis was examined by measuring the dye accumulating in cell. Data represent mean $\pm \mathrm{SD}$ of three separate experiments. $(* p$ $<0.05$ and ${ }^{* *} p<0.01$ vs. the sample treated with same condition without catalase). b Differentiated cells were treated by $4 \mathrm{mM}$ $\mathrm{H}_{2} \mathrm{O}_{2}$ for $6 \mathrm{~h}$ and stained with dye. c Undifferentiated and differentiated cells cultured in $60 \mathrm{~mm}$ dish were treated by $60 \mathrm{mU} / \mathrm{ml}$ GOD for $6 \mathrm{~h}$. After fixing with 4\% PFA, the chromatin condensation was analyzed by Hoechst 33258 staining. Undif 
undifferentiated cell; Dif differentiated cell.

Fig. 3 GOD induced mRNA expression of FoxO3a. Undifferentiated and differentiated cells cultured in $60 \mathrm{~mm}$ dish were treated with $60 \mathrm{mU} / \mathrm{ml}$ GOD for $3 \mathrm{~h}$ and total RNA and protein were extracted. The expression levels of FoxO were examined using RT-PCR (a) and Western blotting (b) in both cells. Band densities were quantified with the ImageJ, and it was shown in a graph as a relative value against control $(0 \mathrm{~h})$. Undif undifferentiated cell; Dif differentiated cell.

Fig. 4 GOD increased FoxO3a protein expression in nuclear and cytosol. Undifferentiated (a) and differentiated cells (b) cultured in $60 \mathrm{~mm}$ dish were treated with $60 \mathrm{mU} / \mathrm{ml}$ GOD for $3 \mathrm{~h}$. The nuclear and cytosolic extracts were prepared as described in "Materials and Methods". The localization of FoxO1 and FoxO3a protein were detected by Western blotting. Band densities were quantified with the ImageJ, and it was shown in a graph as a relative value against control $(0 \mathrm{~h})$.

Fig. 5 GOD induced apoptosis by increasing bim expression via FoxO3a. a Undifferentiated adipocytes cultured in $60 \mathrm{~mm}$ dish were treated with $60 \mathrm{mU} / \mathrm{ml}$ GOD for $3 \mathrm{~h}$ and total RNA was extracted. The Bad, Bax and Bim mRNA levels were examined using RT-PCR. b Undifferentiated adipocytes cultured in $60 \mathrm{~mm}$ dish were infected by adenovirus (Ad-FoxO1Si, Ad-FoxO3aSi, Ad-NCSi) as described “Materials and Methods”. After incubation for $96 \mathrm{~h}$, cells were treated with $60 \mathrm{mU} / \mathrm{ml}$ GOD for $3 \mathrm{~h}$ and total RNA was extracted. The Bad, Bax and Bim mRNA level were examined using RT-PCR. c Undifferentiated adipocytes infected with Ad-FoxO3aSi were treated with $60 \mathrm{mU} / \mathrm{ml}$ GOD for $3 \mathrm{~h}$ and total RNA was extracted. The mRNA level of Bim was examined using real-time PCR. Data represent mean \pm SD of three separate experiments. $(* p<0.05$ vs. N.C. treated with same condition). d Undifferentiated adipocytes infected by Ad-FoxO3aSi were treated with $60 \mathrm{mU} / \mathrm{ml}$ GOD for $6 \mathrm{~h}$. After fixation with 4\% PFA, the chromatin condensation was analyzed using Hoechst 33258 staining.

Fig. 6 Gene expression of antioxidative enzymes in 3T3-L1 cells. a Undifferentiated and differentiated cells were cultured in 60 mm dish and total RNA was extracted. The mRNA levels of each gene were examined by RT-PCR. b Undifferentiated and differentiated cells were cultured and total protein was extracted. The protein level of MnSOD was examined by western blotting. Band densities were quantified with the ImageJ, and it was shown in a graph as a relative value against control (Undif). c Undifferentiated 3T3-L1 infected by Ad-FoxO1Si were treated with $0.2 \mathrm{mU} / \mathrm{ml}$ GOD for 4 days and total RNA was extracted. The mRNA levels of each genes were examined by RT-PCR. Undif undifferentiated cell; Dif differentiated cell. 
Fig.1

A

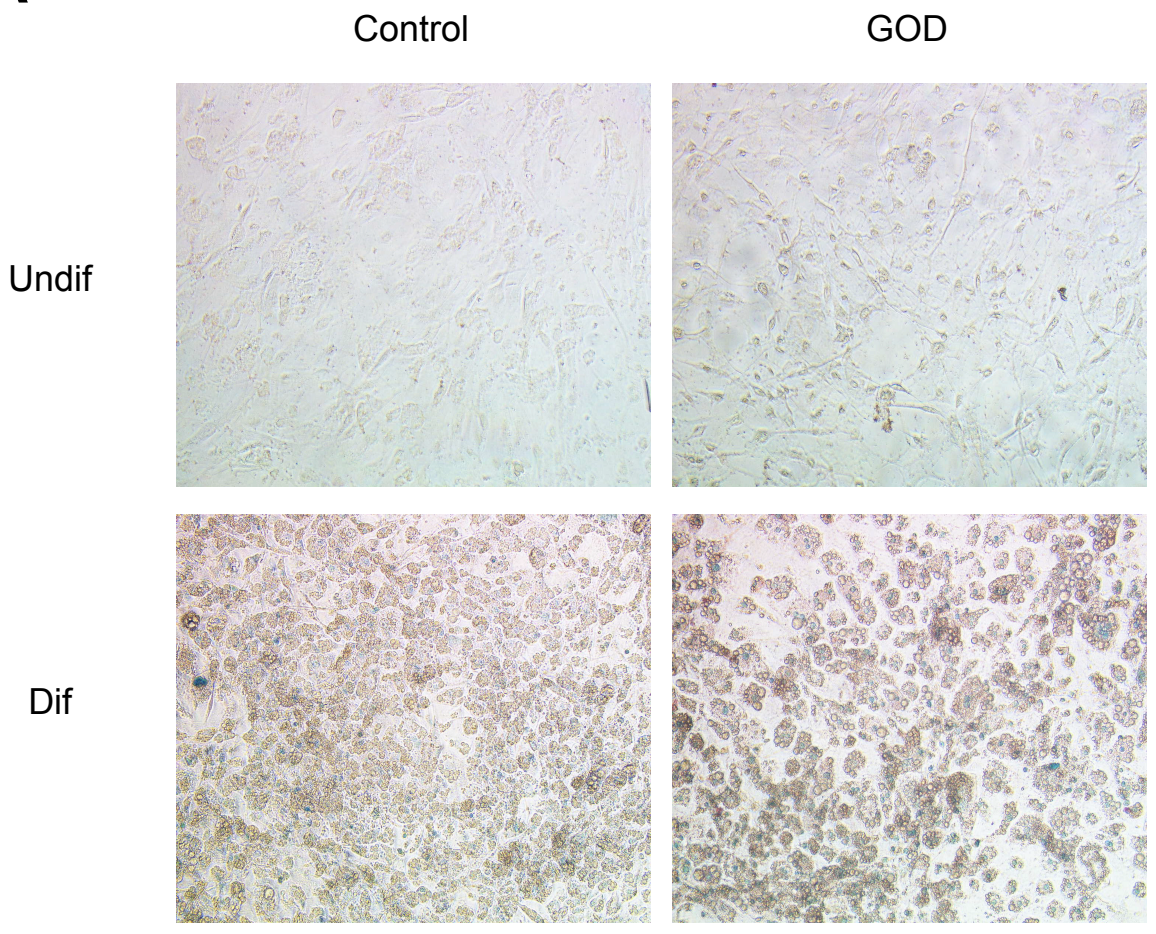

B

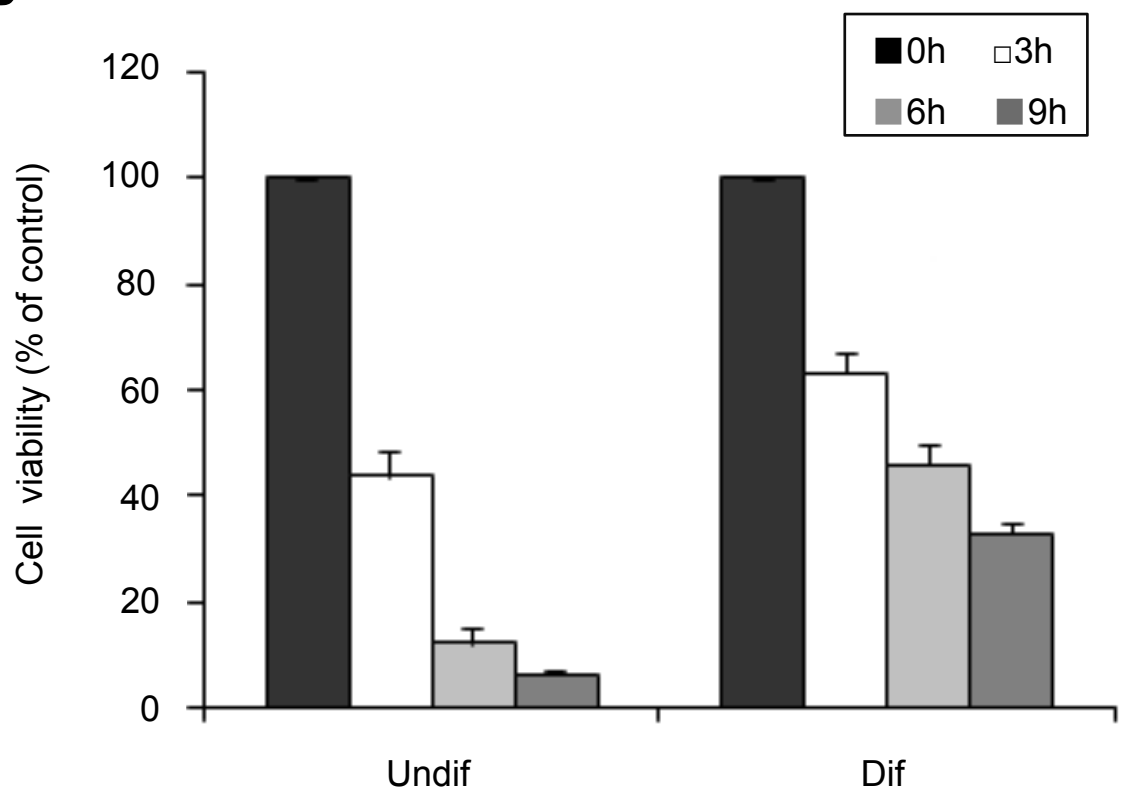


Fig.2

A

Control
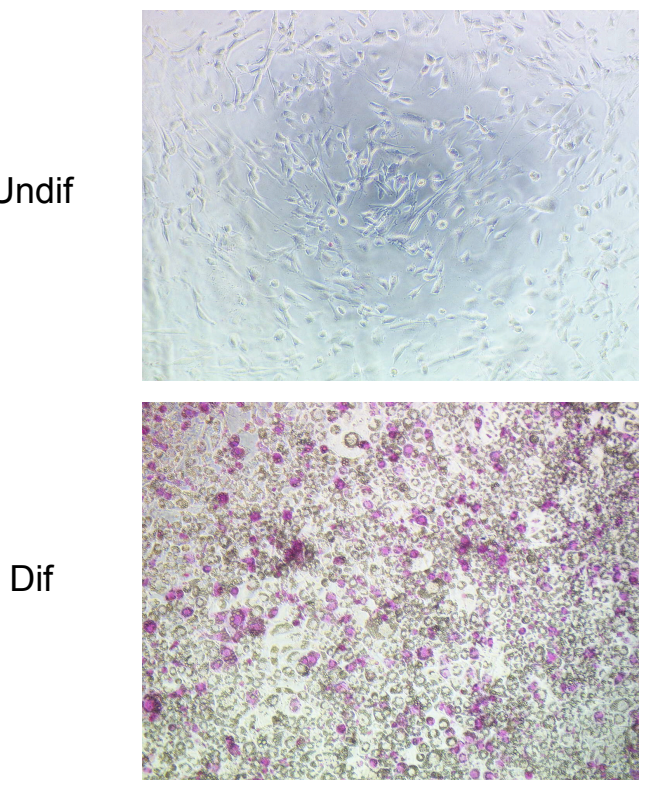

GOD
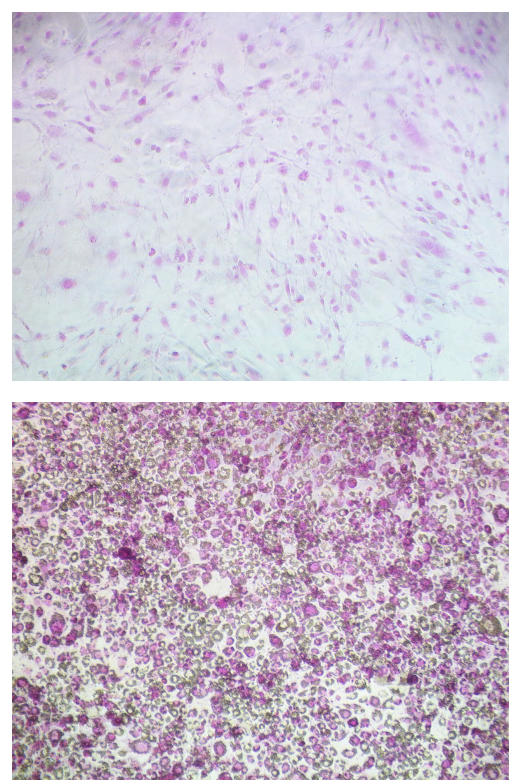

GOD+Cat
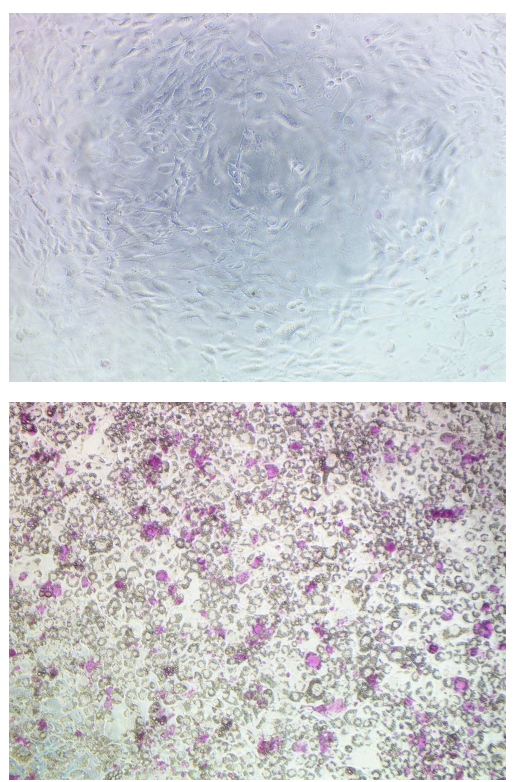

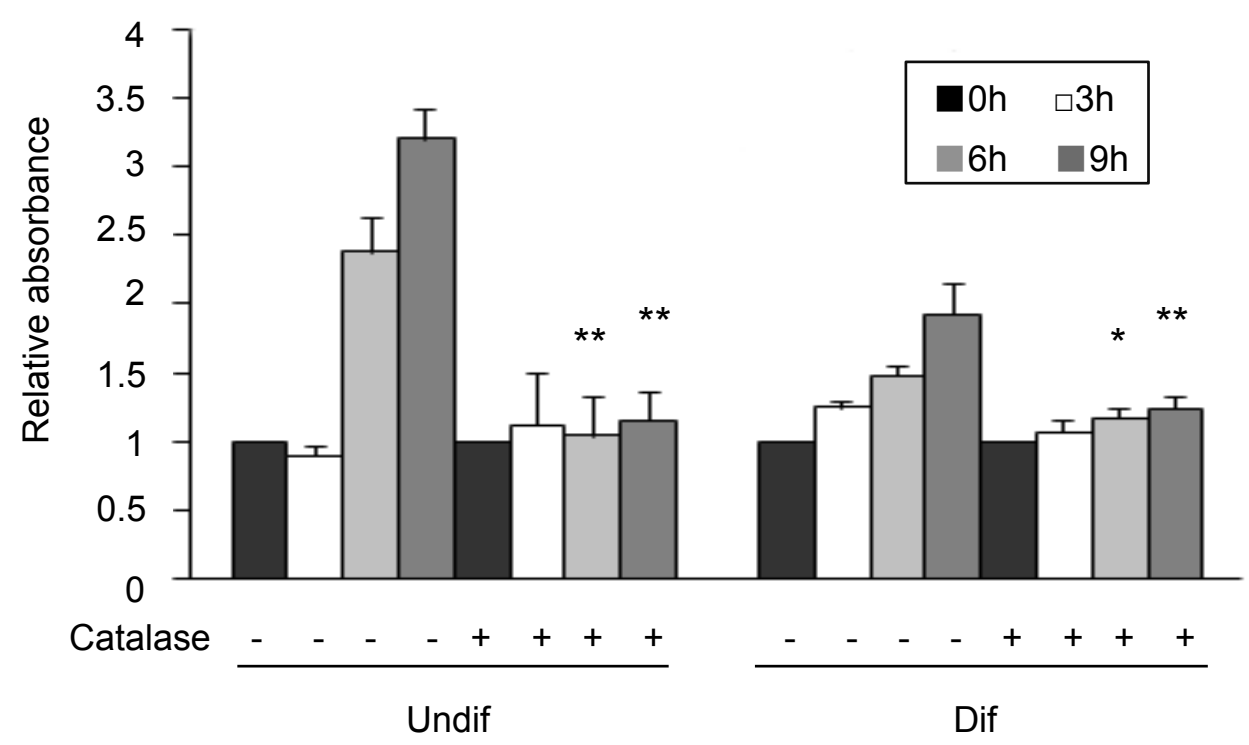

B
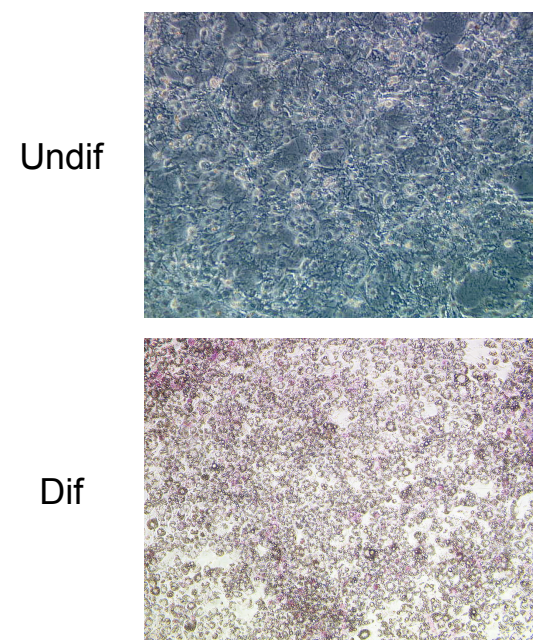

$\mathrm{H}_{2} \mathrm{O}_{2}$

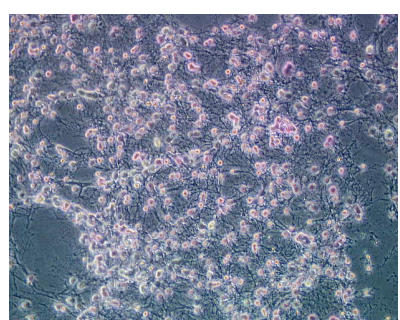

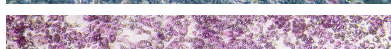

C
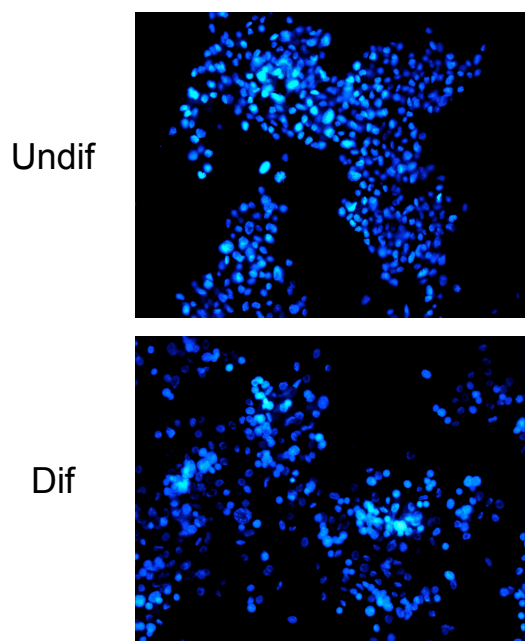
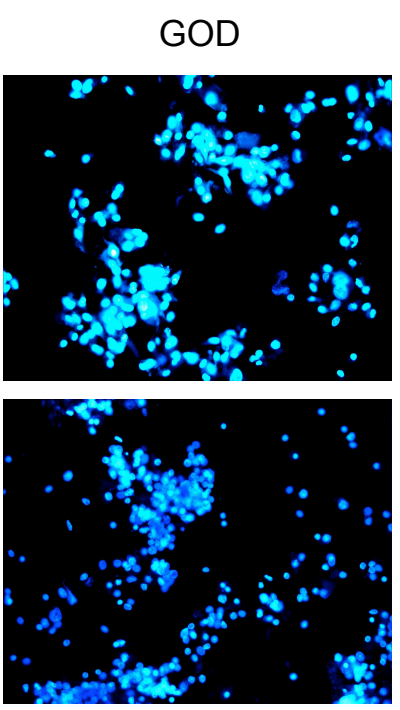
Fig.3
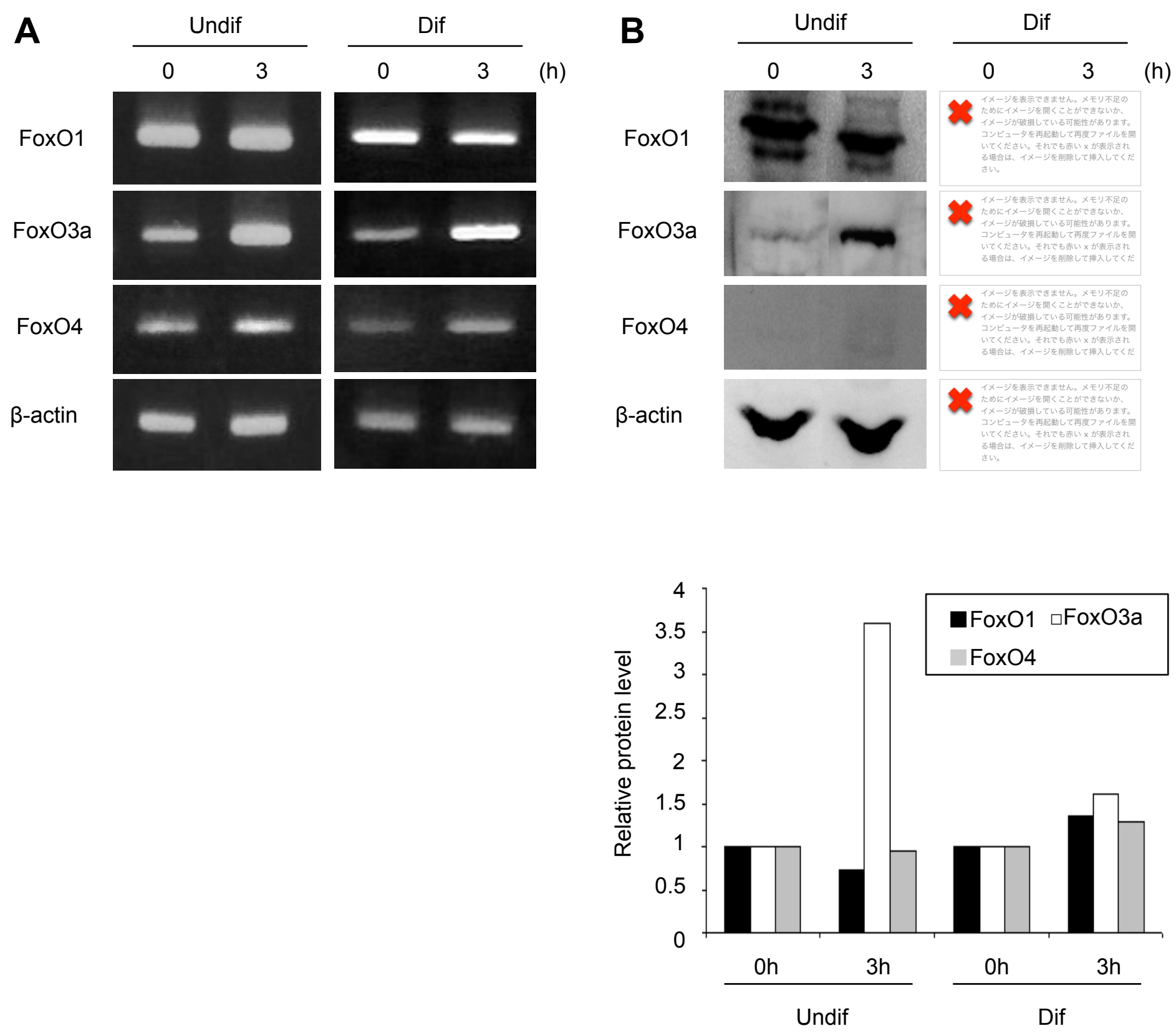
Fig.4
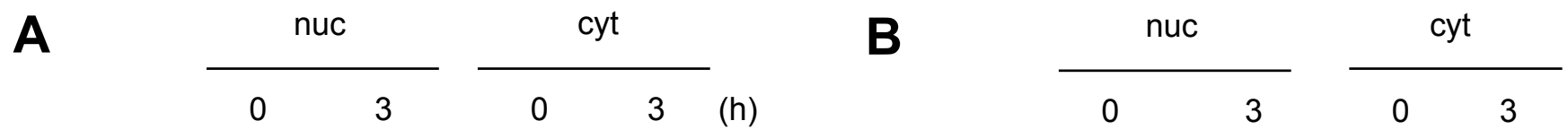

FoxO1

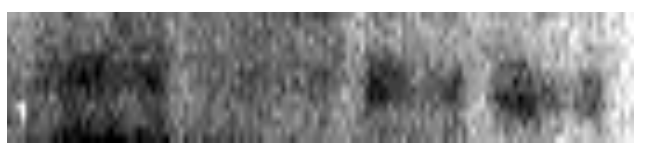

FoxO1

FoxO3a

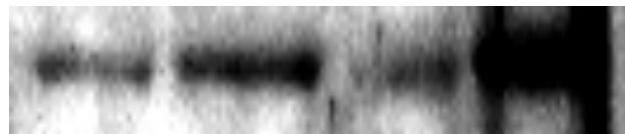

$\beta$-actin

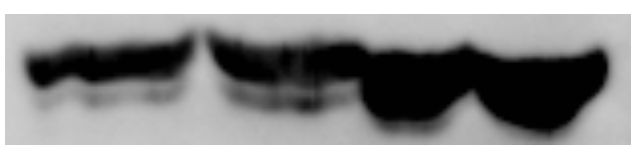

FoxO3a
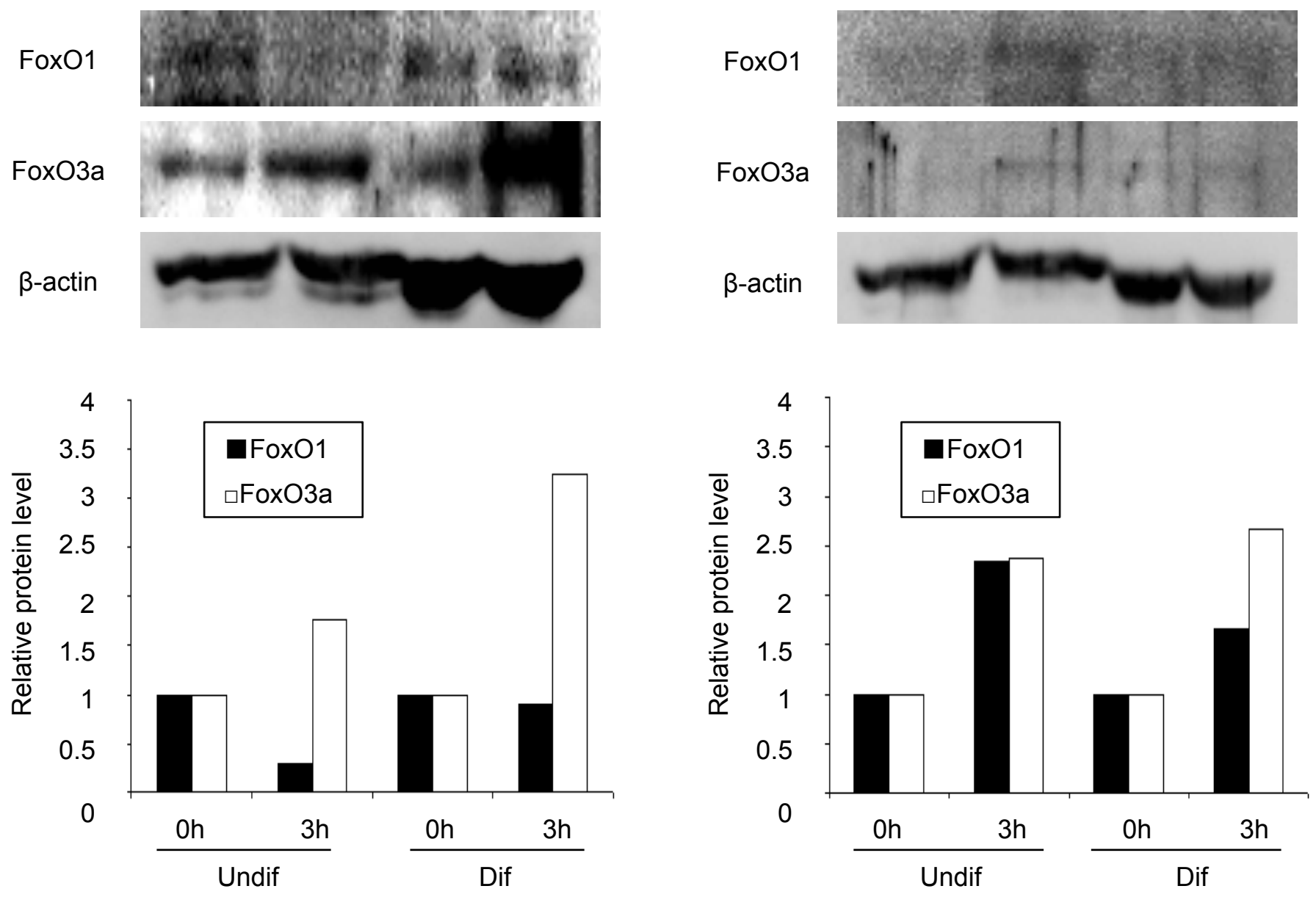


\section{Fig.5}

A

$$
0
$$

3

(h)

Bad

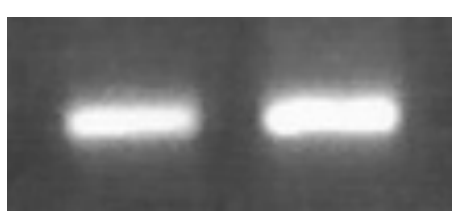

Bax

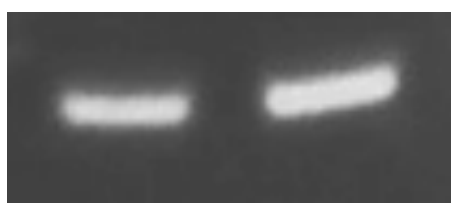

Bim

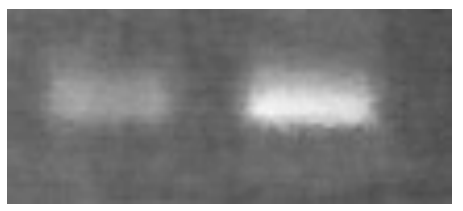

$\beta$-actin

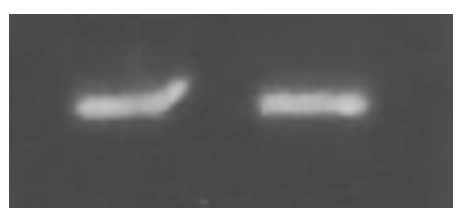

C

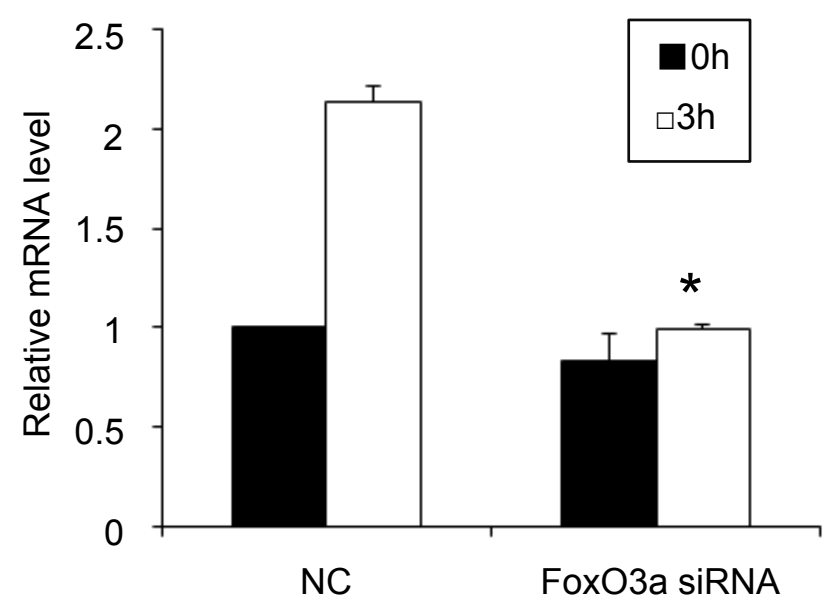

B

siRNA $\quad \frac{\mathrm{NC}}{03} \frac{\text { FoxO1 }}{0} \frac{\text { FoxO3a }}{03} \frac{3}{0}$ (h)

FoxO1

FoxO3a

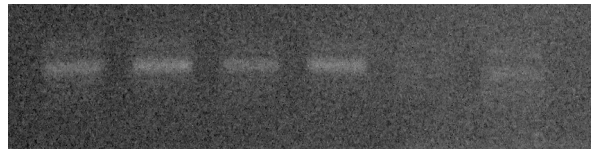

Bad

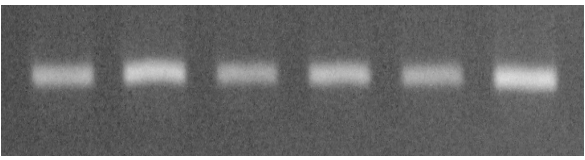

Bax

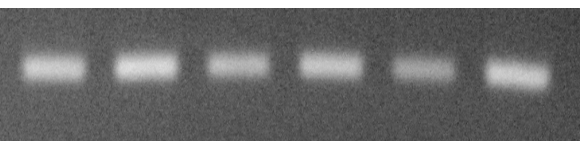

Bim

$\beta$-actin
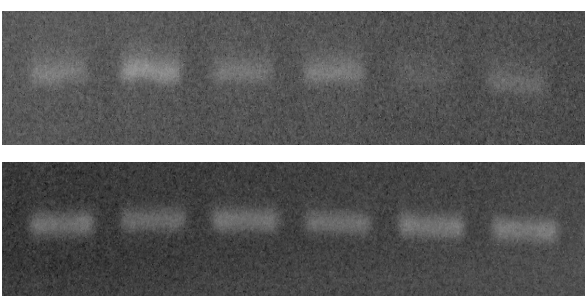

D
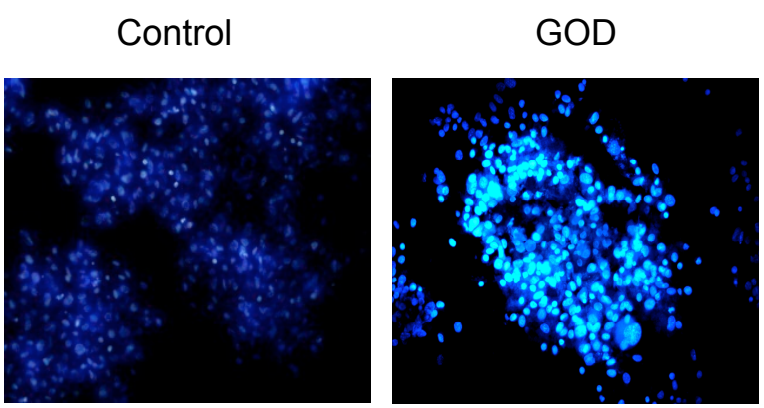

FoxO3a

siRNA
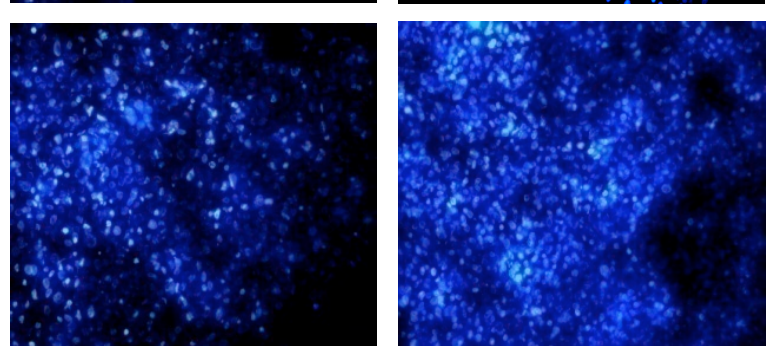
Fig.6

A

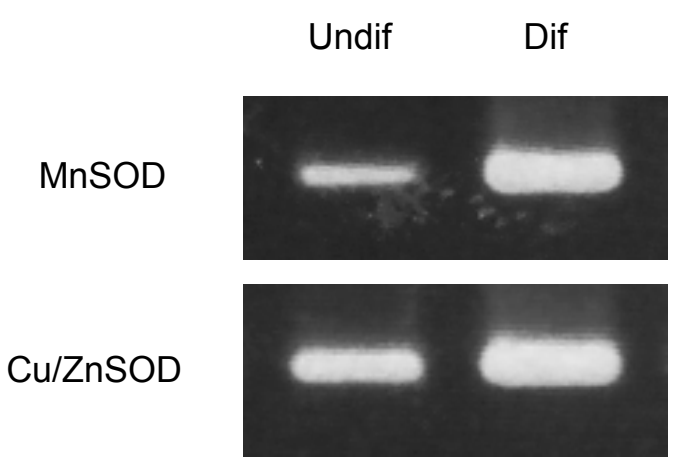

Catalase

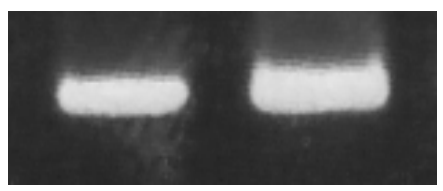

GPX1

FoxO1

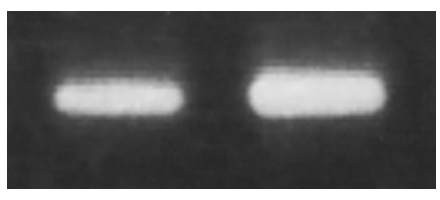

FoxO3a

XX4

im

$\beta$-actin
B
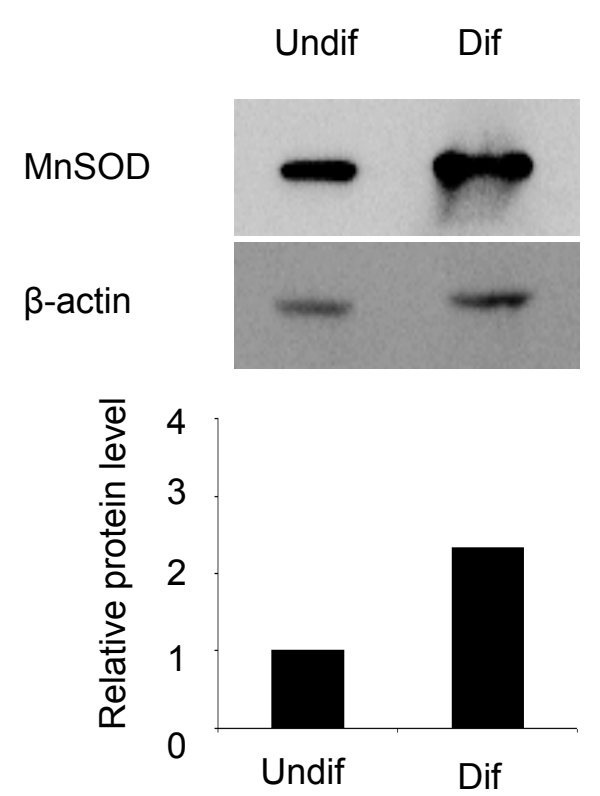

C

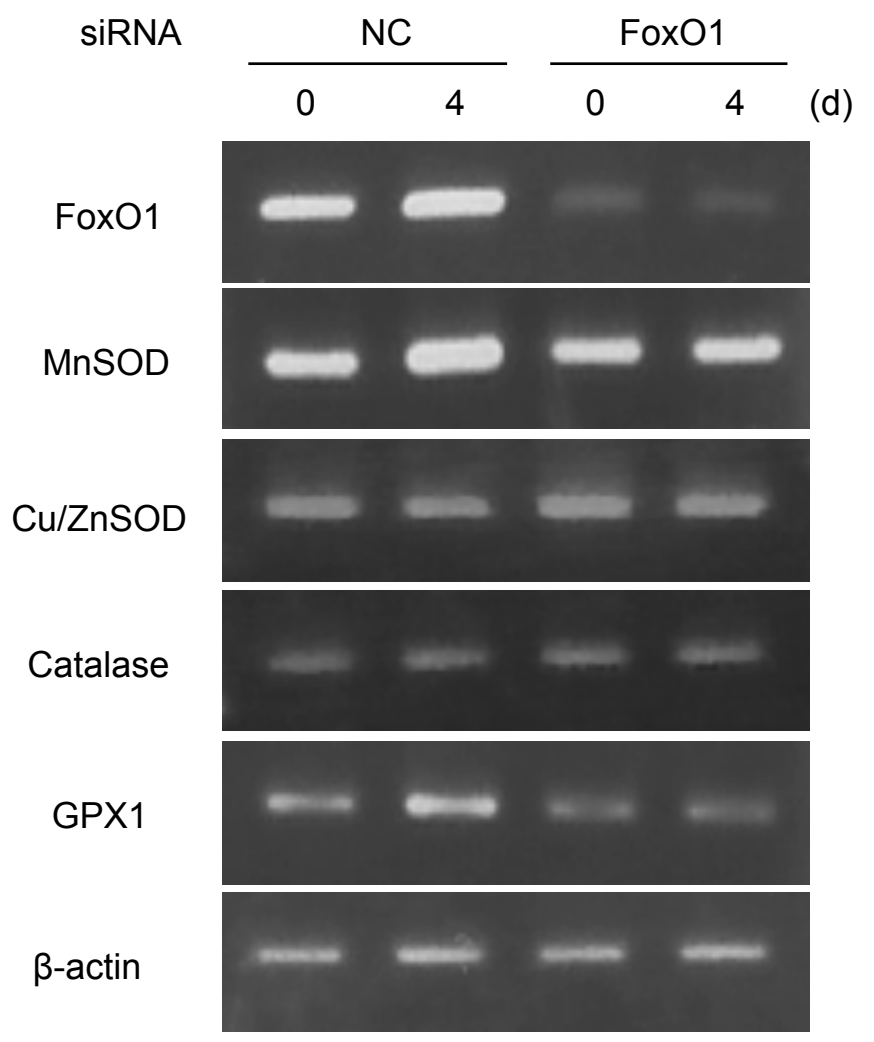




\section{Supplement Figure 1}

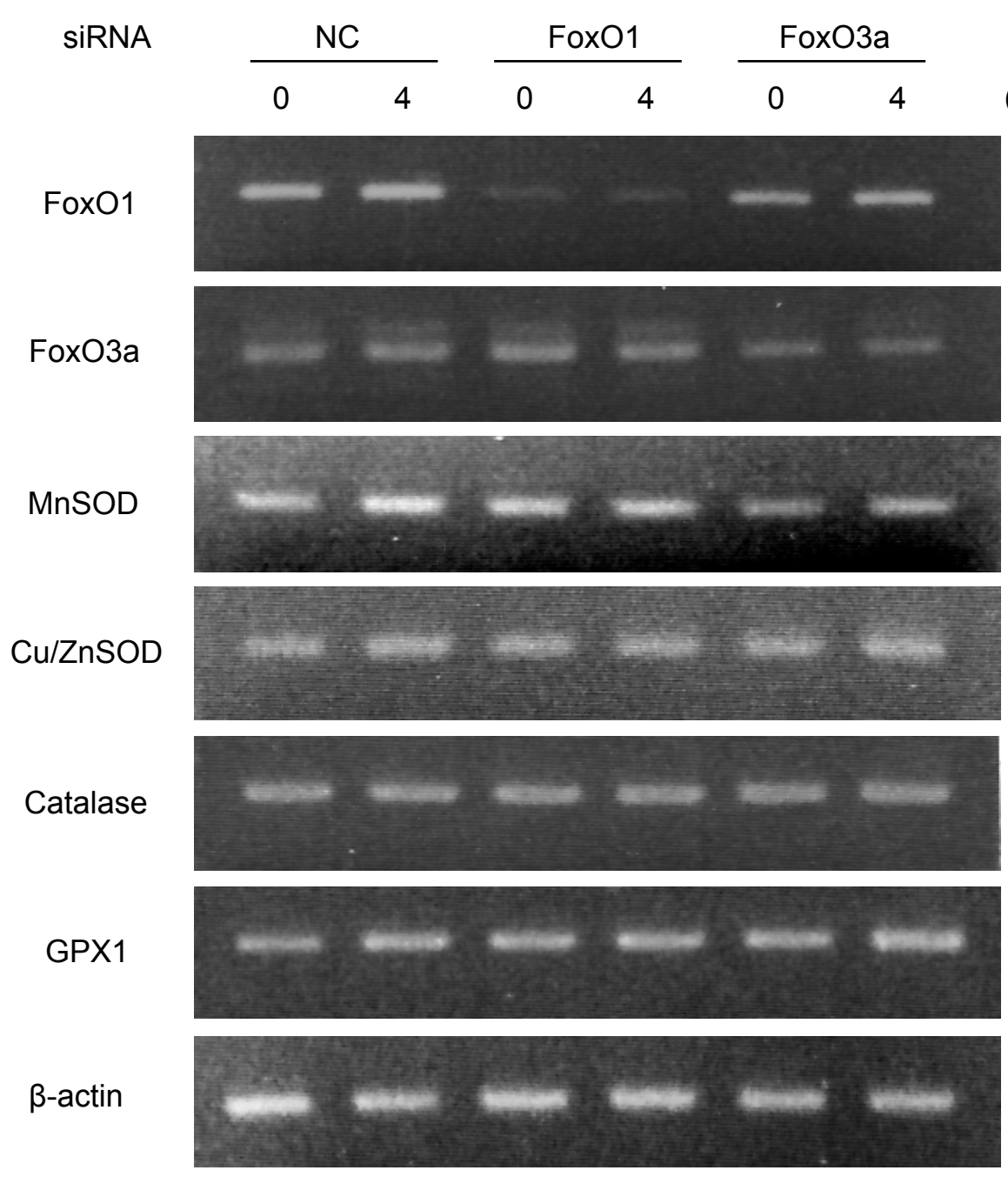


Table 1. Primers for RT-PCR. PCR was performed using the primers indicated as below under optimal amplification conditions ( $95{ }^{\circ} \mathrm{C}$ for $5 \mathrm{~min} ; 22-40$ cycles of $95^{\circ} \mathrm{C}$ for $1 \mathrm{~min}, 57{ }^{\circ} \mathrm{C}$ for $30 \mathrm{sec}, 72{ }^{\circ} \mathrm{C}$ for $1.5 \mathrm{~min} ; 72{ }^{\circ} \mathrm{C}$ for $7 \mathrm{~min}$ ) for each gene. The PCR amplification of each cDNA was performed independently using three samples in triplicate.

\begin{tabular}{llc}
\hline Name & Forward & Reverse \\
\hline '-actin & 5'-CCGGGACCTGACGGACTACCTCATGAAGAT-3' & 5'-AATAGTGATGACTTGGCCGTCAGGCAGCTC-3' \\
FoxO1 & 5'-CAGCGTAGACGCCATCTT-3' & 5'-CAGCGTAGACGCCATCTT-3' \\
FoxO3a & 5'-GACCTGCTGGATAACATC-3' & 5'-GTTTGCATAGACTGGCTG-3' \\
FoxO4 & 5'-CTTCTCTTTGCAGCATCC-3' & 5'-TCCATGAGGTCACTGATG-3' \\
Bad & 5'-CCAGAGTTTGAGCCGAGT-3' & 5'-TTCCTAAGGCCTCGAAAG-3' \\
Bax & 5'-TCATCCAGGATCGAGCAG-3' & 5'-TGTCCAGCCCATGATGGT-3' \\
Bim & 5'-ATGGCAAAGCAACCTTCTG-3' & ''-TCAATGCATTCTCCACACC-3' \\
MnSOD & 5'-AACGCGCAGATCATGCAG-3' & 5'-TGAAGGTAGTAAGCGTGC-3' \\
Cu/ZnSOD & 5'-TTAACTGAAGGCCAGCAT-3' & 5'-CAGATGAGTCTGAGACTC-3' \\
Catalase & 5'-TTGGCCTCACAAGGACTA-3' & 5'-GGCAATGTTCTCACACAG-3' \\
GPX1 & 5'-CATTGAGAATGTCGCGTC-3' & 5'-GCCTTAGGAGTTGCCAGA-3' \\
\hline
\end{tabular}

